\title{
Size and dry weight of main zooplankton species in Bariri reservoir (SP, Brazil)
}

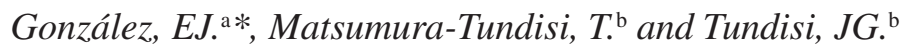 \\ anstituto de Biología Experimental, Universidad Central de Venezuela, \\ Apartado 47106, Los Chaguaramos, Caracas 1041, Venezuela \\ ${ }^{b}$ Instituto Internacional de Ecologia, Rua Bento Carlos 750, Centro, CEP 13560-660, São Carlos, SP, Brazil \\ *e-mail: ergonza@ reacciun.ve \\ Received March 27, 2006 - Accepted August 21, 2006 - Distributed February 29, 2008
}

(With 1 figure)

\begin{abstract}
In order to generate a database for secondary production studies in the São Paulo State (Brazil) reservoirs, the size and dry weight of 13 zooplankton species from Bariri reservoir (middle Tietê River) were determined. Diameter and dry weight of eggs from some cladoceran and copepod species were also determined. Sizes varied from $108.6 \mu \mathrm{m}$ (Keratella tropica) to $2488.6 \mu \mathrm{m}$ (females of Argyrodiaptomus azevedoi), while dry weights varied between $0.025 \mu \mathrm{g}$ (K. tropica) and $51.250 \mu \mathrm{g}$ (females of A. azevedoi). Egg diameters varied between $75.0 \mu \mathrm{m}$ (Mesocyclops ogunnus) and $171.8 \mu \mathrm{m}$ (Ceriodaphnia silvestrii), while egg dry-weights varied between $0.074 \mu \mathrm{g}$ (Acanthocyclops robustus) and $0.865 \mu \mathrm{g}$ (Bosmina hagmanni). Size and dry weight distribution of the zooplanktonic organisms was not linear in the Bariri reservoir.
\end{abstract}

Keywords: zooplankton, size, dry weight, Bariri reservoir, São Paulo and Brazilian reservoirs.

\section{Tamanho e peso seco das principais espécies de zooplâncton no reservatorio de Bariri (SP) Brasil}

\section{Resumo}

Com a finalidade de gerar uma base de dados para o estudo da produção secundária nos reservatórios do Estado de São Paulo, foram determinados o comprimento e o peso seco de indivíduos de 13 espécies do zooplâncton do reservatório Bariri (médio rio Tietê). Também foram determinados o diâmetro e o peso seco dos ovos de algumas espécies de cladóceros e copépodos. Os comprimentos variaram entre 108,6 $\mu \mathrm{m}$ (Keratella tropica) e 2488,6 $\mu \mathrm{m}$ (fêmeas de Argyrodiaptomus azevedoi), e os valores de pesos secos variaram entre 0,025 $\mu \mathrm{g}$ (K. tropica) e 51,250 $\mu \mathrm{g}$ (fêmeas de A. azevedoi). Os diâmetros dos ovos variaram entre 75,0 $\mu \mathrm{m}$ (Mesocyclops ogunnus) e 171,8 $\mu \mathrm{m}$ (Ceriodaphnia silvestrii) e os pesos secos variaram entre 0,074 $\mathrm{g}$ (Acanthocyclops robustus) e 0,865 $\mu \mathrm{g}$ (Bosmina hagmanni). A distribuição do comprimento e do peso seco dos organismos não foi do tipo linear no reservatório Bariri.

Palavras-chave: zooplâncton, comprimento, peso seco, reservatório Bariri, reservatórios de São Paulo e Brasil.

\section{Introduction}

Zooplankton density, expressed as number per area or volume units, does not necessarily provide accurate information about community biomass, because zooplankton consists of a great variety of groups or animal species of a large size range (Matsumura-Tundisi et al., 1989). Moreover, the biomass of the zooplankton species is an important and necessary parameter to calculate the secondary production of this community (Melão and Rocha, 2004).

There are many studies which register the dry weight of zooplankton from temperate ecosystems (Masundire, 1994), but there are few articles concerning the zooplankton biomass for tropical freshwaters (Matsumura-Tundisi et al., 1989; Infante et al., 1990; Masundire, 1994; Melão and Rocha, 2004; Sendacz et al., 2006). Even for temperate regions, direct measures of this parameter are few (Pauli, 1989), probably because organisms ranging between 0.1 and $100 \mu \mathrm{g}$ dry weight are difficult to weigh (Culver et al., 1985). On the other hand, the determination of zooplankton size is an important tool for building the size - weight regressions, which are useful when only size data is available.

Due to these reasons, estimation of zooplankton size and dry weight constitutes an important contribution for the study of trophic-web structure in aquatic ecosystems, considering its relationship with the trophic status of the water bodies (Rocha et al., 1995; Pinto-Coelho et al., 2005). 


\section{Study Area}

Bariri reservoir is located in the middle basin of the Tietê River, in São Paulo State, Brazil. It was built in order to generate hydroelectricity, and to provide drinking water, irrigation and recreation (Barbosa et al., 1999).

The main morphometric features of the reservoir are shown in Table 1. It is a eutrophic reservoir, with high mean concentrations of total phosphorus $\left(87.0 \mu \mathrm{g} . \mathrm{L}^{-1}\right)$, total nitrogen (2750.0 $\left.\mu \mathrm{g} . \mathrm{L}^{-1}\right)$, and chlorophyll- $a$ (55.8 $\left.\mu \mathrm{g} \mathrm{L}^{-1}\right)$; Cyanobacteria dominates the phytoplankton community (Barbosa et al., 1999).

\section{Materials and Methods}

The adult zooplankton specimens were taken from samples stored in the "Museum of Zooplankton" at the International Institute of Ecology (located in the city of São Carlos, São Paulo State, Brazil). These samples were collected from the limnetic region of the Bariri reservoir, and preserved in $4 \%$ formaldehyde (final concentration) which, according to Bottrell et al. (1976), does not affect in a significant way the zooplankton organisms. The studied specimens had less than four years of storage time.

Table 1. Main morphometric features of Bariri reservoir (From: Barbosa et al., 1999).

$$
\begin{aligned}
& \text { Latitude: } 22^{\circ} 09.821^{\prime} \mathrm{S} \\
& \text { Longitude: } 48^{\circ} 44.357^{\prime} \mathrm{W} \\
& \text { Area }\left(\mathrm{km}^{2}\right): 63 \\
& \text { Average depth }(\mathrm{m}): 8.6 \\
& \text { Volume (m } \left.{ }^{3}\right): 542,000,000 \\
& \text { Retention time (days): 7-24 }
\end{aligned}
$$

Standard length (size) and dry weight of the main zooplankton species were determined. Cladocerans: Bosmina hagmanni Stingelin, Ceriodaphnia silvestrii Daday, Daphnia gessneri Herbst and Diaphanosoma spinulosum Herbst. Copepods: Argyrodiaptomus azevedoi Kiefer, Notodiaptomus cearensis Wright, Notodiaptomus evaldus, Notodiaptomus iheringi Wright, Acanthocyclops robustus Sars and Mesocylcops ogunnus Onabamiro. Rotifers: Asplanchna sieboldi Leydig and Keratella tropica Apstein. Ostracods: specimens belonging to the Cypridae family. The number, diameter and dry weight of eggs from $B$. hagmanni, C. silvestrii, $N$. cearensis, $N$. evaldus, $N$. iheringi, A. robustus and $M$. ogunnus, were also determined.

Direct measures were made as follows:

- Sizes and egg diameters were obtained by means of a stereoscopic microscope Leica MZ6 with a calibrated plate ( $2 \mathrm{~mm}, 10 \mu \mathrm{m}$ per division).

- Dry weight was calculated after drying organisms and eggs for 20 hours at $60{ }^{\circ} \mathrm{C}$ (Edmondson and Winberg, 1971). Weights were estimated using a microbalance Mettler MT5 (precision $0.001 \mathrm{mg}$ ).

- For statistical analysis, One-Way ANOVA was applied in order to search for significant differences $(\mathrm{p}<0.05)$ among analyzed species-sizes and among egg diameters. A Two-Way ANOVA was applied in order to search for significant differences between size of males and females in the different calanoid copepods species. For these statistical analyses, the "STATISTICA" program, version 7 (StatSoft, Inc., 2004) was employed.

\section{Results}

Table 2 shows sizes and dry weights of main zooplankton species of Bariri reservoir. Few specimens of

Table 2. Mean length and dry weight of the main zooplankton species in Bariri reservoir.

\begin{tabular}{lccc}
\hline \multicolumn{1}{c}{ Species } & N & Mean length $(\mu \mathbf{m})$ & Mean dry weight $(\mu \mathbf{g})$ \\
\hline Argyrodiaptomus azevedoi male & 6 & $2125.9 \pm 75.2$ & 32.500 \\
Argyrodiaptomus azevedoi female & 8 & $2488.6 \pm 120.9$ & 51.250 \\
Notodiaptomus iheringi male & 15 & $1100.0 \pm 68.2$ & 5.267 \\
Notodiaptomus iheringi female & 12 & $1227.8 \pm 52.5$ & 6.083 \\
Notodiaptomus cearensis male & 12 & $1303.4 \pm 53.0$ & 9.667 \\
Notodiaptomus cearensis female & 19 & $1363.9 \pm 65.7$ & 9.842 \\
Notodiaptomus evaldus male & 18 & $1249.3 \pm 63.5$ & 8.056 \\
Notodiaptomus evaldus female & 19 & $1472.1 \pm 70.2$ & 11.842 \\
Acanthocyclops robustus female & 22 & $1226.0 \pm 32.2$ & 10.136 \\
Mesocyclops ogunnus female & 28 & $1129.9 \pm 33.2$ & 8.786 \\
Ceriodaphnia silvestrii & 25 & $577.9 \pm 38.3$ & 1.440 \\
Bosmina hagmanni & 29 & $394.3 \pm 48.7$ & 1.897 \\
Diaphanosoma spinulosum & 30 & $769.7 \pm 119.3$ & 2.233 \\
Daphnia gessneri & 58 & $1006.0 \pm 155.6$ & 4.197 \\
Keratella tropica & 40 & $108.6 \pm 6.0$ & 0.025 \\
Asplanchna sielboldi & 23 & $1366.0 \pm 143.9$ & 4.174 \\
Ostracoda (Family Cypridae) & 19 & $530.5 \pm 71.8$ & 3.211 \\
\hline
\end{tabular}


Argyrodiaptomus azevedoi were collected $(\mathrm{n}=14)$, but they showed the highest values of size and dry weight in this reservoir. On the other hand, Keratella tropica showed the lowest values of size and dry weight.

Figure 1 represents the size and dry weight distribution of the selected zooplankton species. It was evidenced that as the size increased, weight increased too; however, this distribution does not have a linear shape.

\subsection{Calanoid copepods}

Size of the different calanoid copepods species (Factor 1) and sex (Factor 2) were compared using a TwoWay ANOVA (Table 3). Significant differences ( $<<0.05$ ) were found between female and male sizes (females showed bigger sizes than males). Argyrodiaptomus azevedoi was the biggest species, followed by Notodiaptomus evaldus, which showed significant differences from $N$. cearensis and $N$. iheringi. In addition, no significant differences were found between $N$. cearensis and $N$. iheringi sizes. Interaction of Factor 1 and Factor 2 was significant, indicating a synergistic effect between size and sex.

\subsection{Cyclopoid copepods}

Calanoid copepods were considered apart, because the factor "sex" could not be included in the analysis (see Table 3). Among cyclopoid copepods, Acanthocyclops robustus was significatively bigger $(\mathrm{p}<0.05)$ than Mesocyclops ogunnus (Table 4).

\subsection{Cladocerans}

Significant differences $(\mathrm{p}<0.05)$ were found among cladoceran sizes (Table 4). The "Less Significant
Difference" (LSD) test confirmed that Daphnia gessneri was the biggest species, followed by Diaphanosoma spinulosum, Ceriodaphnia silvestrii and Bosmina hagmanni.

Table 5 shows egg mean diameters and dry weights of some cladoceran and cyclopoid copepod species. Cyclopoid copepod eggs were the smaller and lighter ones. Ceriodaphnia silvestrii eggs showed the highest mean diameter, while the Bosmina hagmanni eggs had the highest dry weight.

Table 3. Significant results $(\mathrm{p}<0.05)$ of the Two-Way ANOVA comparisons between calanoid sex and species size. Aa: Argyrodiaptomus azevedoi, Ne: Notodiaptomus evaldus, Nc: Notodiaptomus cearensis, and Ni: Notodiaptomus iheringi.

\begin{tabular}{lrc}
\hline \multicolumn{1}{c}{ Factor } & \multicolumn{1}{c}{ F } & LSD comparisons \\
\hline Size & 852.69 & $\mathrm{Aa}>\mathrm{Ne}>\mathrm{Nc}=\mathrm{Ni}$ \\
Sex & 164.19 & Females $>$ Males \\
Interaction & 16.32 & \\
\hline
\end{tabular}

Table 4. Significant results $(\mathrm{p}<0.05)$ of the One-Way ANOVA comparisons between zooplankton group sizes and egg diameters. Bh: Bosmina hagmanni, Cs: Ceriodaphnia silvestrii, Dg: Daphnia gessneri, Ds: Diaphanosoma spinulosum, Ar: Acanthocyclops robustus, Mo: Mesocyclops ogunnus.

\begin{tabular}{crl}
\hline Group & \multicolumn{1}{c}{ F } & \multicolumn{1}{c}{ LSD comparisons } \\
\hline 1) Cladocerans & 63.73 & $\mathrm{Dg}>\mathrm{Ds}>\mathrm{Cs}>\mathrm{Bh}$ \\
2) Cyclopoids & 108.62 & $\mathrm{Ar}>\mathrm{Mo}$ \\
\hline
\end{tabular}

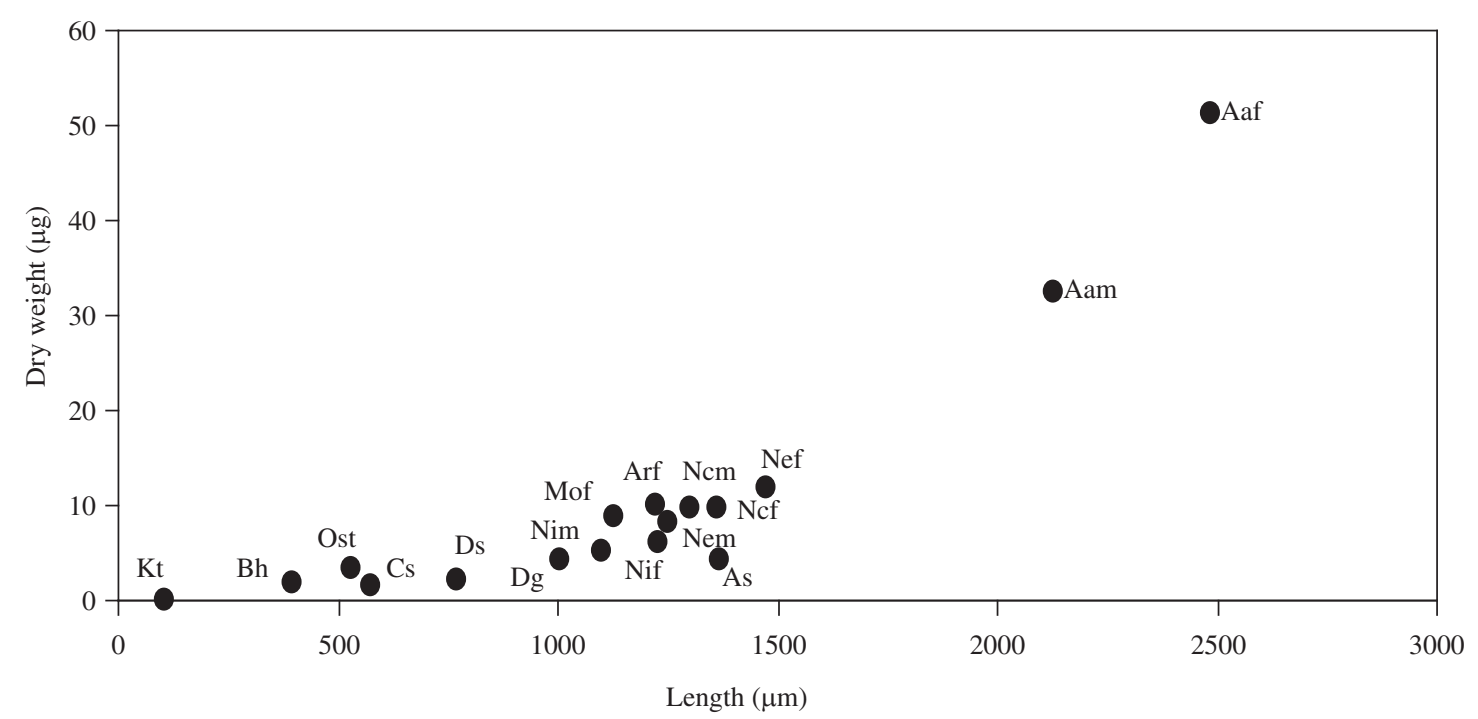

Figure 1. Zooplankton dry weight and size distribution in Bariri reservoir. Kt: Keratella tropica, Ost: Ostracoda, As: Asplanchna sieboldi, Bh: Bosmina hagmanni, Cs: Ceriodaphnia silvestrii, Ds: Diaphanosoma spinulosum, Dg: Daphnia gessneri, Mof: Mesocyclops ogunus - female, Arf: Acanthocyclops robustus - female, Nim: Notodiaptomus iheringi - male, Nif: Notodiaptomus iheringi - female, Ncm: Notodiaptomus cearensis - male, Ncf: Notodiaptomus cearensis - female, Nem: Notodiaptomus evaldus - male, Nef: Notodiaptomus evaldus - female, Afm: Argyrodiaptomus azevedoi - male, Aaf: Argyrodiaptomus azevedoi - female. 


\subsection{Copepod eggs}

Notodiaptomus iheringi (3 eggs in one ovigerous central sack) showed the largest egg diameter for the calanoid species, followed by $N$. evaldus (4-7 eggs per ovigerous sack) and $N$. cearensis (6-10 eggs per ovigerous sack), whereas N. evaldus eggs showed diameters significatively larger than the $N$. cearensis eggs $(\mathrm{p}<0.05)$. On the other hand, no significant differences were found among cyclopoid copepod egg diameters (A. robustus and M. ogunnus). A. robustus showed 78-92 eggs disposed in two ovigerous sacks, while $M$. ogunnus showed 54-60 eggs also disposed in two ovigerous sacks.

\subsection{Cladoceran eggs}

Only Ceriodaphnia silvestrii and Bosmina hagmanni eggs were compared. B. hagmanni carried out 2-6 eggs per female, while $C$. silvestrii had 1-4 eggs per female. The ANOVA test showed no significant differences ( $p>0.05$ ) between the egg diameters.

\subsection{Eggs (general)}

Egg diameters for all studied species were compared. The a posteriori analysis (LSD) showed significant differences $(\mathrm{p}<0.05)$ among them. Comparisons showed four homogeneous groups: $N$. iheringi and $C$. silvestrii eggs showed the biggest diameter and no significant differences between them; egg diameters of $N$. iheringi specimens were different from the rest of the analyzed eggs; $C$. silvestrii eggs showed no significant differences with the B. hagmanni and N. evaldus egg diameters; and eggs from $N$. evaldus showed no significant differences with $N$. cearensis eggs, which showed significatively higher egg diameters than the cyclopoid copepod ( $A$. robustus and $M$. ogunnus) eggs.
Table 6 shows a general summary of the One-Way ANOVA results after comparison among egg diameters of the studied species.

\section{Discussion}

Results showed that as size increases, the weight increases too, but not in a linear way. Keratella tropica showed the smallest weight among the studied species, while the highest one was obtained for Argyrodiaptomus azevedoi; this species was 3-5 times larger than Notodiaptomus evaldus (female), which was the following species considering the dry weight. In relation to size, Argyrodiaptomus azevedoi almost duplicated Notodiaptomus evaldus length, while the smallest studied species was the rotifer Keratella tropica. Although A. azevedoi seemed to be scarce in the samples, this species probably contributes in a high degree to the total biomass of the zooplankton community in the Bariri reservoir. As reported in many tropical freshwater ecosystems, copepods could represent the major contribution of zooplankton biomass in Bariri reservoir, while rotifers constitute a minor fraction of total biomass (Infante, 1993; Matsumura-Tundisi et al., 1989; González et al., 2002; Melão and Rocha, 2004). However, there are cases where cladocerans may show the highest values of biomass in other water bodies (Sendacz et al., 2006).

There are few studies related to zooplankton dry weight or biomass in tropical systems (Masundire, 1994). In tropical South America, information seems to be restricted to some Venezuelan and Brazilian water bodies.

In Venezuela, some authors describe zooplankton variations on a biomass basis. For example, Carrillo (2001) found, in La Mariposa reservoir (hypertrophic), that total

Table 5. Egg mean diameters and dry weights of the main zooplankton species in Bariri reservoir.

\begin{tabular}{lccc}
\hline \multicolumn{1}{c}{ Species } & N & Mean diameter $(\mu \mathbf{m})$ & Mean dry weight $(\mu \mathbf{g})$ \\
\hline Acanthocyclops robustus & 486 & $75.4 \pm 3.2$ & 0.074 \\
Mesocyclops ogunnus & 306 & $75.0 \pm 4.1$ & 0.105 \\
Notodiaptomus iheringi & 78 & $166.8 \pm 8.2$ & 0.474 \\
Notodiaptomus evaldus & 95 & $161.2 \pm 7.1$ & 0.589 \\
Notodiaptomus cearensis & 64 & $146.5 \pm 10.9$ & 0.365 \\
Bosmina hagmanni & 74 & $161.3 \pm 25.2$ & 0.865 \\
Ceriodaphnia silvestrii & 30 & $171.8 \pm 16.0$ & 0.367 \\
\hline
\end{tabular}

Table 6. Results of the One-Way ANOVA comparisons among zooplankton group egg diameters ( $\mathrm{p}<0.05$ ). Bh: Bosmina hagmanni, Cs: Ceriodaphnia silvestrii, Dg: Daphnia gessneri, Ds: Diaphanosoma spinulosum, Ar: Acanthocyclops robustus, Mo: Mesocyclops ogunnus, Ne: Notodiaptomus evaldus, Nc: Notodiaptomus cearensis, and Ni: Notodiaptomus iheringi.

\begin{tabular}{lccl}
\hline \multicolumn{1}{c}{ Group } & F & Significant? & \multicolumn{1}{c}{ LSD comparisons } \\
\hline 1) Notodiaptomus & 82.30 & Yes & $\mathrm{Ni}>\mathrm{Ne}>\mathrm{Nc}$ \\
2) Cyclopoid & 0.21 & $\mathrm{No}$ & $\mathrm{Ar}=\mathrm{Mo}$ \\
3) Cladoceran & 3.60 & $\mathrm{No}$ & $\mathrm{Cs}=\mathrm{Bh}$ \\
4) Eggs (general) & 1.32 & $\mathrm{Mes}$ & 1) $\mathrm{Ni}=\mathrm{Cs}$ \\
& & 2) $\mathrm{Ni}>\mathrm{Bh}=\mathrm{Ne}>\mathrm{Nc}>\mathrm{Ar}=\mathrm{Mo}$ \\
& & 3) $\mathrm{Cs}=\mathrm{Bh}=\mathrm{Ne}>\mathrm{Nc}>\mathrm{Ar}=\mathrm{Mo}$ \\
\end{tabular}


zooplankton biomass ranged between $273.49 \mu \mathrm{g} . \mathrm{L}^{-1}$ and $1056.15 \mu \mathrm{g} . \mathrm{L}^{-1}$ during a 15 -months study period, while González (2002) reported a mean total zooplankton biomass of $48.51 \mu \mathrm{g} . \mathrm{L}^{-1}$ in the oligotrophic Agua Fría reservoir, and González et al. (2002) calculated a mean value of $27.71 \mu \mathrm{g} . \mathrm{L}^{-1}$ in the oligotrophic Taguaza reservoir. On the other hand, the oligo-mesotrophic Tierra Blanca reservoir showed a mean value of $607.21 \mu \mathrm{g} . \mathrm{L}^{-1}$ of total zooplankton biomass (González, 2004).

Sendacz et al. (2006) also found higher total zooplankton biomass in the eutrophic Guarapiranga reservoir (between 80.74 and $356.81 \mu \mathrm{g} . \mathrm{L}^{-1}$, for the rainy and dry seasons, respectively) as compared with the oligotrophic Ponte Nova reservoir (between 11.61 and $14.12 \mu \mathrm{g} . \mathrm{L}^{-1}$, for the rainy and dry seasons, respectively) in the upper Tietê River basin (São Paulo State, Brazil).

These examples clearly evidenced a relationship between the zooplankton biomass and the trophic state of the reservoirs. Eutrophic reservoirs can support the high abundance of zooplankton, which has no food limitation in highly productive ecosystems (González et al., 2002). Thus, eutrophication affects structure, size and biomass of the zooplankton community (Pinto-Coelho et al., 2005).

Infante (1993), calculated the biomass (as dry weight) of the main zooplankton groups in the hypertrophic Lake Valencia (Venezuela), in the dry and rainy seasons. For copepods, the biomass values were $78.8 \mu \mathrm{g} . \mathrm{L}^{-1}$ (dry season) and $61.1 \mu \mathrm{g} . \mathrm{L}^{-1}$ (rainy season); for cladocerans, $15.7 \mu \mathrm{g} . \mathrm{L}^{-1}$ (dry season) and $14.7 \mu \mathrm{g} . \mathrm{L}^{-1}$ (rainy season); for rotifers, $5.1 \mu \mathrm{g} . \mathrm{L}^{-1}$ (dry season) and 17.2 $\mu \mathrm{g} . \mathrm{L}^{-1}$ (rainy season); and finally, for protozoans $1.0 \mu \mathrm{g} . \mathrm{L}^{-1}$ (dry season) and $7.1 \mu \mathrm{g} . \mathrm{L}^{-1}$ (rainy season). Similar patterns were found by Sendacz et al. (2006) in the Brazilian Ponte Nova and Guarapiranga reservoirs (Brazil), where the total zooplankton biomass was found to decrease in the rainy season, when total pigments and total suspended solids showed lower values. Food abundance, type and quality seemed to be involved in these observed patterns in Lake Valencia, and Ponte Nova and Guarapiranga reservoirs.

In relation to specific dry weights, information is scarce in South America. In Venezuela, Infante et al. (1990) estimated the dry weights of some zooplankton species from Lake Valencia as follows: Notodiaptomus deeveyorus Bowman (adult female) $6.98 \mu \mathrm{g}$, Thermocyclops decipiens Kiefer $3.02 \mu \mathrm{g}$ (adult), Ceriodaphnia cornuta Sars $1.49 \mu \mathrm{g}$, Moina micrura Kurz $1.84 \mu \mathrm{g}$, Keratella americana Carlin $0.08 \mu \mathrm{g}$, Brachionus calyciflorus Pallas $0.67 \mu \mathrm{g}$ and Brachionus havanaensis Rousselet $0.40 \mu \mathrm{g}$. As well as observed for Bariri species, rotifers showed the lower values while copepods showed the higher ones.

Matsumura-Tundisi et al. (1989) estimated length and dry weight of the main zooplankton species in the oligo-mesotrophic Broa reservoir (Brazil). The values of length and dry weight reported for adult specimens were, respectively, as follows: Argyrodiaptomus furcatus Sars female $1.43 \mathrm{~mm}$ and $17.80 \mu \mathrm{g}$; A. furcatus male $1.25 \mathrm{~mm}$ and $11.90 \mu \mathrm{g}$; Thermocyclops minutus Lowndes female and male $0.60 \mathrm{~mm}$ and $0.78 \mu \mathrm{g}$; Bosminopsis deitersi Richard $0.34 \mathrm{~mm}$ and $0.61 \mu \mathrm{g}$; Bosmina hagmanni and B. tubicen $0.40 \mathrm{~mm}$ and $0.89 \mu \mathrm{g}$; Moina minuta Hansen $0.47 \mathrm{~mm}$ and $0.92 \mu \mathrm{g}$; Diaphanosoma brachyurum Lievin $0.62 \mathrm{~mm}$ and $0.98 \mu \mathrm{g}$. Sizes and dry weights were lower than those that were estimated in Bariri reservoir, probably as a consequence of the lower level of eutrophication at Broa reservoir, in which food limitation for zooplankton could occur.

Melão and Rocha (2004) determined size and dry weight for organisms and eggs belonging to two cyclopoid copepods species from Lagoa Dourada (Brazil). Sizes and dry weights, at $25^{\circ} \mathrm{C}$, were as follows: Tropocyclops prasinus Fischer female $520 \mu \mathrm{m}$ and $2.24 \mu \mathrm{g}$; T. prasinus male $419 \mu \mathrm{m}$ and $0.88 \mu \mathrm{g} ;$ T. prasinus eggs $39 \mu \mathrm{m}$ and $0.20 \mu \mathrm{g} ;$ Mesocyclops longisetus Thiébaud female $1560 \mu \mathrm{m}$ and $14.00 \mu \mathrm{g} ;$ M. longisetus male $917 \mu \mathrm{m}$ and $4.33 \mu \mathrm{g} ; M$. longisetus eggs $86 \mu \mathrm{m}$ and $0.39 \mu \mathrm{g}$. These cyclopoid copepods showed higher values of size and dry weight than those that were estimated for the cyclopoid copepods in Bariri reservoir.

In every cited study, females were bigger and heavier than the male specimens. In addition, it can be noted that calanoid eggs were larger and heavier than the cyclopoid ones, because cyclopoid copepods develop a greater number of eggs for their reproduction (Infante, 1988).

Some values obtained for freshwater zooplankton from other latitudes, including Hall et al. (1970), that reported direct measures of dry weight for many freshwater zooplankton species, some of which belong to the same genus found in Bariri reservoir, are as follows: Bosmina longirostris Muller $1.8 \mu \mathrm{g}$; Ceriodaphnia reticulata Jurine $4.2 \mu \mathrm{g}$; Daphnia pulex De Geer $35.0 \mu \mathrm{g}$ and Diaphanosoma brachyurum $7.0 \mu \mathrm{g}$. Except for B. longirostris, the rest of the values seem to be high in extreme, if compared with results obtained for Bariri reservoir; probably, the reported data in the Hall et al. study were obtained by different procedures than those followed in this study.

Burgis (1974) reported the "formalin" dry weight and length for two cyclopoid species. Adult female without eggs of Thermocyclops hyalinus Rehberg and Mesocyclops leuckarti Claus showed mean length of 631 and $1023 \mu \mathrm{m}$, respectively, while the dry weight were 1.19 and $4.13 \mu \mathrm{g}$, respectively. These values are lower than those that were registered for the cyclopoid species of Bariri reservoir.

Masundire (1994), reported size and dry weight values for some zooplankton species from Lake Kariba (tropical Africa): Bosmina longirostris $299.0 \mu \mathrm{m}$ and $0.86 \mu \mathrm{g}$; Ceriodaphnia cornuta $568.6 \mu \mathrm{m}$ and $1.56 \mu \mathrm{g}$; Diaphanosoma excisum $791.4 \mu \mathrm{m}$ and $1.81 \mu \mathrm{g}$; Thermocyclops sp. female $750.0 \mu \mathrm{m}$ and $1.77 \mu \mathrm{g}$; Thermocyclops sp. male $638.2 \mu \mathrm{m}$ and $0.98 \mu \mathrm{g}$; Tropodiaptomus sp. female and male $1239.0 \mu \mathrm{m}$ and $5.27 \mu \mathrm{g}$. These calculations were similar to those that were obtained in the Bariri reservoir for the Bosmina, Ceriodaphnia and Diaphanosoma genus.

Although there are some indirect methods for calculations of dry weight in zooplankton, as the use of 
equations, direct measures are more reliable. For example, Pauli (1989) found that transformation of body volumes, which is commonly used as an estimate of fresh weight, with a general conversion factor of $10 \%$ dry weight of body volume, does not reflect the differences among rotifer species, which can contain more than $90 \%$ of water in their bodies, resulting in unsatisfactory values. However, direct and indirect measures can be combined, in order to obtain accurate estimates of biomass (Culver et al., 1985), but organisms must be collected over a long period of time, in order to represent the seasonal variation of weight per length that occurs in nature.

Values reported in the literature are diverse, even for a same genus and/or species, which often make the use of comparative approaches unviable (Sendacz et al., 2006). This can be attributed to the use of different methodologies, which should be taken into account when dry weight calculations are made. For example, according to some authors, preservation with formaldehyde could result in loss of the zooplankton weight in a 10-47\% range (Burgis, 1974; Blettler and CóstaBonecker, 2006), although Dumont et al. (1975) and Bottrell et al. (1976) stated that there is no significant loss of weight in the planktonic organisms that are fixed with $4 \%$ formaldehyde.

Although only adult specimens were analyzed in this study, results obtained represent a valuable and useful database for the study of secondary production in tropical freshwater ecosystems; this kind of information is scarce in this region, especially in South America. Moreover, this database could be useful in comparing zooplanktonic community conditions, which are related with the trophic status of each aquatic system.

In addition, other recommendations should be taken into consideration, in order to conduct a more complete study for the zooplankton size and dry weight relationships. It is not sufficient that only a simple distribution of size and weight for zooplankton species should be represented; the relationship between the size classes and their corresponding weights should be constructed for each species (Wetzel and Likens, 2001; Blettler and Cósta-Bonecker, 2006). Variation along the climatic periods should be incorporated, with the aim of obtaining representative and reliable data for the secondary production calculation of the water bodies.

Acknowledgments - the authors thank Odete Rocha, for her comments during the development of this research, as well as the staff of the International Institute of Ecology, for their technical support in the determination of the zooplankton dry-weight. E. J. González also thanks the Consejo de Desarrollo Científico y Humanístico de la Universidad Central de Venezuela $(\mathrm{CDCH}$ - UCV) and the Conselho Nacional de Desenvolvimento Científico e Tecnolôgico (CNPq), for their financial support to his sabbatical activities in the International Institute of Ecology at São Carlos, Brazil. E. González-Waite helped with the English translation.

\section{References}

BARBOSA, FAR., PADISÁK, J., ESPÍNDOLA, ELG., BORICS, G. and ROCHA, O., 1999. The cascading reservoir continuum concept (CRCC) and its application to the river Tietêbasin, São Paulo State, Brazil. Theoretical reservoir ecology and its applications. Edited by TUNDISI, JG. and STRASKRABA, M. International Institute of Ecology, Brazilian Academy of Sciences and Backhuys Publishers, p. 425-437.

BLETTLER, M. and CÓSTA-BONECKER, C., 2006. Avaliação da biomassa de microcrustáceos em ambientes aquáticos continentais. Interciencia, vol. 31, no. 8, p. 591-597.

BOTTRELL, HH., DUNCAN, A., GLIWICZ, ZM., GRYGIEREK, E., HERZIG, A., HILBRICHT-ILKOWSKA, A., KURAZAWA, H., LARSSON, P. and WEGLENSKA, T., 1976. A review of some problems in zooplankton production studies. Norw. J. Zool., vol. 24, no. 4, p. 419-456.

BURGIS, MJ., 1974. Revised estimates for the biomass and production of zooplankton in Lake George, Uganda. Freshwater Biol., vol. 4, no. 6, p. 535-541.

CARRILLO, VM., 2001. Distribución espacial del zooplancton en el embalse La Mariposa (Distrito Capital) de julio a diciembre de 2000. (Trabajo Especial de Grado) - Universidad Central de Venezuela. Caracas, $41 \mathrm{p}$.

CULVER, DA., BOUCHERLE, MM., BEAN, DJ. and FLETCHER, JW., 1985. Biomass of freshwater crustacean zooplankton from length - weight regressions. Can. J. Fish. Aq. Sci., vol. 42, no. 8, 1380-1390.

DUMONT, HJ., VAN DE VELDE, I. and DUMONT, S., 1975. The dry weight estimate of biomass in a selection of Cladocera, copepods and rotifers from the plankton, periphyton and benthos of continental waters. Oecologia, vol. 19 , no. 1 , p. $75-97$.

EDMONDSON, WT. and WINBERG, GG. (Eds.)., 1971. A manual on methods for the assessment of secondary productivity in fresh waters. Blackwell. Oxford, IBP Handbook no. 17, $358 \mathrm{p}$.

GONZÁLEZ, EJ., 2002. Caracterización limnológica de los embalses Agua Fría (Estado Miranda) y Tierra Blanca (Estado Guárico). Proyecto S1 - 98001361. Etapa I: Caracterización limnológica del embalse Agua Fría (Parque Nacional Macarao, Estado Miranda). Informe técnico presentado al FONACIT. Caracas.

-, 2004. Caracterización limnológica de los embalses Agua Fría (Estado Miranda) y Tierra Blanca (Estado Guárico). Proyecto S1 - 98001361. Etapa II: Caracterización limnológica del embalse Tierra Blanca (Estado Guárico). Informe técnico presentado al FONACIT. Caracas.

GONZÁLEZ, EJ., ORTAZ, M., MATOS, ML., MENDOZA, J., PEÑAHERRERA, C. and CARRILLO, VM., 2002. Zooplancton de dos embalses neotropicales con distintos estados tróficos. Interciencia, vol. 27, no. 10, p. 551-558.

HALL, DJ., COOPER, WE. and WERNER, EE., 1970. An experimental approach to the production dynamics and structure of freshwater animal communities. Limnol. Oceanogr., vol. 15, no. 6, p. 839-928.

INFANTE, A., 1988. El plancton de las aguas continentales. Secretaría General de la Organización de los Estados 
Americanos. Programa Regional de Desarrollo Científico y Tecnológico. Monografía, Washington, DC, no. 33, 130 p.

-, 1993. Vertical and horizontal distribution of the zooplankton in Lake Valencia. Acta Limnologica Brasiliensia, vol. 6, no. 1, p. 97-105.

INFANTE, A., INFANTE, O., VEGAS, T. and RIEHL, W., 1990. Estudio comparativo del lago de Valencia (Venezuela) y el lago de Managua (Nicaragua). Informe final. Organización de los Estados Americanos y Universidad Central de Venezuela. Caracas.

MASUNDIRE, HM., 1994. Mean individual dry weight and length-weight regressions of some zooplankton of Lake Kariba. Hydrobiologia, vol. 272, no. 1-3, p. 231-238.

MATSUMURA-TUNDISI, T., RIETZLER, A. and TUNDISI, JG., 1989. Biomass (dry weight and carbon content) of plankton crustacea from Broa reservoir (São Carlos, SP. - Brazil) and its fluctuation across one year. Hydrobiologia, vol. 179, no. 3 p. 229-236.

MELÃO, MGG. and ROCHA, O., 2004. Life history, biomass and production of two planktonic cyclopoid copepods in a shallow subtropical reservoir. J. Plankton Res., vol. 26, no. 8, p. 909-923.
PAULI, HR., 1989. A new method to estimate individual dry weights of rotifers. Hydrobiologia, vol. 186-187, vol 1, p. 355-361.

PINTO-COELHO, RM., BEZERRA-NETO, JF. and MORAIS-JR., CA., 2005. Effects of eutrophication on size and biomass of crustacean zooplankton in a tropical reservoir. Braz. J. Biol., vol. 65, no. 2, p. 325-338.

ROCHA, O., SENDACZ, S. and MATSUMURA-TUNDISI, T., 1995. Composition, biomass and productivity of zooplankton in natural lakes and reservoirs of Brazil. Limnology in Brazil. Edited by TUNDISI, JG., BICUDO, CEM. and MATSUMURA-TUNDISI, T. Brazilian Academy of Sciences and Brazilian Limnological Society, Rio de Janeiro, p. 151-165.

SENDACZ, S., CALEFFI, S. and SANTOS-SOARES, J., 2006. Zooplankton biomass of reservoirs in different trophic conditions in the state of São Paulo, Brazil. Braz. J. Biol., vol. 66 , no. 1b, p. 337-350.

STATSOFT, INC. 2004. STATISTICA (data analysis software system), version 7 .

WETZEL, RG. and LIKENS, GE., 2001. Limnological analyses. $3^{\text {rd }}$ edition. Springer-Verlag. New York, 429 p. 
